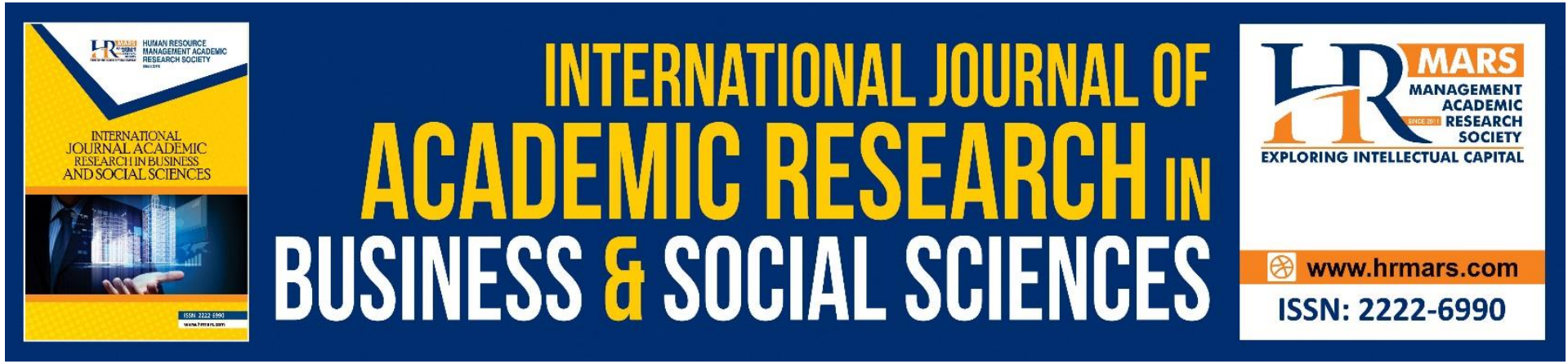

\title{
The Impact of Enterprise Resource Planning System on The Performance of Accountants within Omanis Manufacturing Companies
}

Maryam Al Najadi, Rayhanun Jannat, Mahmood Al Ismaili, Nouf Al Jabri

To Link this Article: http://dx.doi.org/10.6007/IJARBSS/v11-i7/10671

DOI:10.6007/IJARBSS/v11-i7/10671

Received: 21 May 2021, Revised: 30 June 2021, Accepted: 10 July 2021

Published Online: 25 July 2021

In-Text Citation: (Najadi et al., 2021)

To Cite this Article: Najadi, M. Al, Jannat, R., Ismaili, M. Al, \& Jabri, N. Al. (2021). The Impact of Enterprise Resource Planning System on The Performance of Accountants within Omanis Manufacturing Companies. International Journal of Academic Research in Business and Social Sciences, 11(7), 1698-1706.

Copyright: @ 2021 The Author(s)

Published by Human Resource Management Academic Research Society (www.hrmars.com)

This article is published under the Creative Commons Attribution (CC BY 4.0) license. Anyone may reproduce, distribute, translate and create derivative works of this article (for both commercial and non-commercial purposes), subject to full attribution to the original publication and authors. The full terms of this license may be seen

at: http://creativecommons.org/licences/by/4.0/legalcode

Vol. 11, No. 7, 2021, Pg. 1698 - 1706

Full Terms \& Conditions of access and use can be found at http://hrmars.com/index.php/pages/detail/publication-ethics 


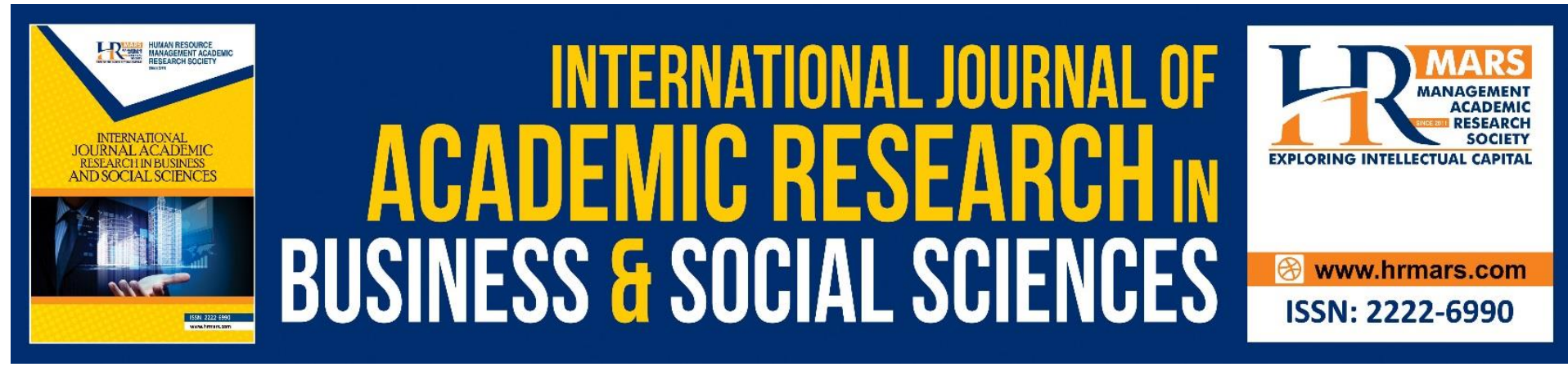

\title{
The Impact of Enterprise Resource Planning System on The Performance of Accountants within Omanis Manufacturing Companies
}

\author{
Maryam Al Najadi, Rayhanun Jannat, Mahmood Al Ismaili, \\ Nouf Al Jabri \\ Faculty of Business Sohar University, Oman \\ Email: 160312@students.su.edu.om,171414@students.su.edu.om, \\ 171083@students.su.edu.om,151661@students.su.edu.om
}

\begin{abstract}
The accounting department plays a substantial role in a company's success. The Enterprise Recourse Planning system (ERP) is a tool that has been used in companies to help them complete their roles. This research study aims to examine the impact of the ERP system on the performance of accountants and the difficulties and challenges faced by the accountants in Oman in using the ERP system. This research has been investigated using primary data. Online interviews were held with accountants from 4 different manufacturing companies in Oman. A snowball sampling technique was used in selecting the companies. Sample target is the manufacturing companies located in Oman, Al Batinah Region. The data has been analyzed by using qualitative data and using within company analysis and cross analysis to analyze the data. The study concluded that the ERP system does have an impact on accountant's performances and even though ERP system helps in reducing cost and improving accountant's performance and work efficiency, implementing the system is expensive and requires proper training and adequate knowledge.
\end{abstract}

Keywords: Accounting Practices, ERP, Management Accountant, Interrogated Accounting System.

\section{Introduction}

The accountant role includes collecting, recording, analyzing, and reporting of financial data. In the past, the accountant will have to utilize vary basic, manual, and time-consuming methods; data collection is done in person and the records are registered on a traditional file system. Complex analysis is most of the time very hard to perform and sometimes even impossible. For the business, this is not only time consuming but could also cost a lot of money. However, with the advancement of technology, new systems have emerged to assist businesses and accountants. The Enterprise Resource Planning (ERP) system is a group of software designed to "coordinate all the resources, information, and activities needed to complete business processes such as order fulfillment or billing. (Swapnil \& Mullick, 2010). ERP system often provides a single real-time database supporting the different business functions. 
During the 1960s, sensational advancement in the area of computer hardware and software occurred, and the evaluation of ERP followed. During that time, most of the businesses have developed and executed integrated computing systems that were mostly controlling their inventory automatically. However, the ERP system truly came into sight in the late 1980s and the start of the 1990s for the first time with the ability of enterprise-wide inter-functional coordination and integration (Target Population.). Furthermore, ERP was first introduced in Oman in 2013. ERP is used, to manage and unify the major components of the business. There are several ERP software. These ERP software applications help companies implement resource planning by combining all the methods required to run their business in one integrated system. The applications also enable easy communication between the different departments of the company and make sharing information easier.

This research paper, aims to analyze the impact of ERP systems on the performance of accountants and examine the difficulties faced by them in using the ERP system. ERP system became very popular software among companies. This system helped many companies control the process of business by tracking and reporting the resources and it helped them improve the management of databases and the information system (Labarre\& Anderson, 2021). Also, this system allows the companies to expand their growth without costing them much. In addition, the accounting department in many companies depends on this system to manage their work such as in allocating the cost of activities, managing the payments, set up budgets, and many other jobs (Heele, 2019). For that, the knowledge of the ERP system is very important, but in the world the implementation rate of ERP system is still low. There are many researchers who wrote about the ERP system in many different aspects, but none of them have discussed the implementation of the ERP system in the manufacturing companies of Oman. Therefore, in this research would like to study how this system affects the performance of accountants.

\section{Research Objectives}

The Research Objectives of this research are:

- To examine the impact of the ERP system on the performance of accountants.

- To examine the difficulties faced by the accountant in applying the ERP system.

\section{Research Questions}

The Research Questions of this research are:

- How does the ERP system affect the performance of accountants?

- What are the difficulties faced by the accountant in applying the ERP system?

\section{Literature Review \\ Impact of ERP implementation}

The Enterprise Resource Planning system provides potential advantages and consistent communication for businesses in an organization. The ERP implementation has an impact on the overall process, customs, and the environment of the organization. Seos (2013) study provides a circumstantial understanding of different challenges faced between the corporate and university environment while implementing the ERP system and prove that, both the corporate and universities are getting significant benefits by using the ERP system, although the companies in the corporate sector reorganize their business processes more easily than universities. Indra, Noorlailie, and Isnalita (2018) study concluded that, there is significant difference between the relevance of accounting information and firms' performance of 
companies that adopt ERP system and the companies that do not. Furthermore, they have verified the impact of the ERP implementation on relativity of accounting information and firms' performances. Moreover, Fang, Yi-jun, Ben-nan, and Qiang (2009) study explores the usual method of the usage of ERP in Chinese companies after implementation from the viewpoint of ERP performance. According to them, an ERP performance varies in four stages, which are "passion of novelty", "shake-down", "fast improving", and "stably and continuously improving". The successful implementation of Enterprise resource planning systems (ERP) can provide effective strategies, operational and information-related advantages to the firm. At the same time, an unsuccessful implementation can usually bring economic destruction. Muscatello, Small and Chen (2003) investigated the implementation method of the ERP system in the small and medium-size manufacturing firms in the US. According to them, successful firms in their study had focused on the planning, justification, installation, and commissioning activities. They also propose that there are some traits that are common among the selected companies, in the implementation of modern technologies, especially among the humanfactors associated actions. Simultaneously, Agaoglu, Yurtkoru, \& Ekmekçi (2015) study disclosed that the Critical Success Factors (CSFs) emphasis on significant differences and have an impact on the success of ERP implementation from the user's perspective. Additionally, the significance allocated to CSFs is non-relevance to the actual effect of CSFs on the implementation of ERP system.

\section{ERP on Management Accountants and Accounting Practices}

Enterprise resource planning (ERP) system improves organizational control. Syida, Nawawi, and Salin have investigated the efficiency of implementing the ERP system on controlling the management system in 2009 and they also examined the effect of the ERP system on the accountants' role. The outcome of their study states that the ERP system helps accountants to work more efficiently and improves decision making and helps in controlling the management system in an orderly manner. Sangster, Leech and Grabski (2009) performed a study on the impact of the ERP implementation on the performance of management accountant, management accounting in general, and business process revealed that with successful implementations of ERP systems, management accountants have more time for other exceptional activities and their role becomes more enhancing. On the other hand, with the unsuccessful implementation of ERP systems, increases the role of the management accountant, the absence of the ERP system demands more work from them without any notable decrease in the jobs they usually perform. Sunarni (2013) studied the role of management accountant, the accounting practices of management, and the factor that are encouraging the variations are different between the medium scale and big scale manufacturing firms in Yogyakarta. He revealed in his study that the accounting practices in those companies were managed according to the traditional accounting practices. Additionally, profit improvement and budgeting were considered the most important managerial tool in management accounting practices for both medium and big-scale companies; however, there was a big difference in management, accounting tasks between the companies. Furthermore, he proposed that the management accountants in Yogyakarta should change their roles and become more strategic. Additionally, to improve the quality of management, they should encourage the use of advanced management accounting practices. A study conducted by Alleyne and Marshall in 2011 did to examine the management accounting practice in three manufacturing companies in Barbados. Their study 
presented that the factors influencing the management accounting practice decisions were timeliness, information, technology, and efficiency. Furthermore, the management accounting practices enable the management to obtain relevant information for meaningful decision making. Moreover, Sangster et al (2009) wrote a report on the difference in the role of the accountants between companies that were successful while implementing the ERP system and the companies that were not, along with the experience of some companies in implementing an ERP system in view of changes on the work and behaviors in management accounting. Their study found that the percentage of successes increases when the management accountants participate in the implementation of an ERP system. Galani, Gravas, and Stavropoulos (2010) made a study to examine why Greek companies invest in ERP system and how users benefit from ERP system on using new accounting practice in Greek companies. The researcher approve that the ERP system provide a greater level on information integration, flexibility in information access and greater functionality provided by ERP system.

\section{Research Design and Methodology}

Primary data has been used in this research. Interviews have been conducted to obtain the required data. Online interviews were conducted due to COVID-19. We have prepared a sheet of key questions to make sure that we cover all aspects that we need to know, and the sheet has been given to the respondents before the interview so they can respond in a good manner. Mainly, the interview depended on semi-structured discussions with the accountants. The sample for our research is the manufacturing companies in AL Batinah North Region. For our research we have used a snowball sampling technique. Our sample consists of the firms that have implemented or are on the stage of implementing the ERP system. The totals of 10 companies were approached out of those, 4 companies allowed us to conduct the interview. The position of the respondents in the companies were financial and management accountants. For the data analysis we have used both within company and cross company analysis. This method of study used by some researchers such as (Faudziah and Rababah, 2011; Fadzil, and Rababah, 2012; Rababa'h, 2014; Hasan, 2017; Nassar and Rababah, 2020)

\section{Data Analysis}

This section introduced the analysis of the data that we gathered using interviews. There are two sections to analyze the data, within company analysis and a cross company analysis. Within company analysis used to deeply analyze the impact of ERP system on the performance of the accountants and the difficulties faced by them in implementing the system in each company. It described the important things that we came up about ERP system from the interviews. The cross-company analysis used to compare between the companies and to see the differences and similarities among them. It compared between companies and see the factors of implementation; factors affected the Performance of the accountants and the difficulties faced by them.

\section{Findings and Discussion Implementation of ERP System}

The research shows that there is a strong connection between manufacturing strategy and successful ERP implementations. Company one, two, three, and four have achieved higher efficiency in their work process. ERP implementation had helped the companies in saving valuable time that they can utilize in various jobs now. The ERP system also improves 
information quality that allows ERP to help in decision making. According to the interviewees, implementation of ERP helps businesses in competitive strategies though; all the projects were not successful despite the large investments made. Moreover, ERP systems have established correlations between different departments of the organization. On the other hand, the ERP is managerial software which could result in new risks and problems due to the frequent changes in software and technology. The interviewees have also claimed that the ERP implementation is highly expensive despite even when considering the saving in time and cost to the organization.

\section{Difficulties Faced by Accountants in Using ERP System}

The interviewees were asked about the impact of ERP and the difficulties they have faced during the implementation. According to the interviewees, there were very few difficulties faced while implementing ERP. Most of their responses included that the ERP system requires a definite understanding of the business. They have also responded that ERP implementations changes the task for management accountants which are supported by the study of Sangster, Leech and Grabski (2009). Our findings also indicate that the most faced difficulties among the accountants and the users of ERP are limited to knowledge about the system. According to the interviewees, lack of training has caused them a greater deal of issues which is similar to the finding of the study by Agaoglu, Yurtkoru and Ekmekçi (2015). Moreover, because of the changing technology ERP systems methods and function keeps changing frequently, so the accountants have to keep up to date with the changes. The interviewees have also included that, despite helping in saving time and being efficient, the ERP systems takes a long time while on the implementation phase. All the data and information that are stored in different places require data cleanliness which takes a lot of time and patience from the accountants. Furthermore, the accountants normally face issues adapting the ERP system because it is very different and complex from the traditional system.

\section{Impact on the Performance of Accountants}

The finding of the study indicates that the ERP system greatly influences the performance of the accountants. The accountants have become more involved in the decision-making because of ERP and have improved their efficiency, that is supported by the study of Sangster, at al. (2009). Moreover, the system provides a higher quality of information that gives better assistance for necessary planning. Furthermore, the accessibility of the information has become more efficient. It improves the significance of accounting information and provides reliable up-to-date information. Our findings also indicate that as being an integrated system, ERP helps in reducing time, lessens accounting reporting period, and increases its quality, which results in accounting works being easier than using the traditional system.

\section{Conclusion}

Most of the companies around the world are adopting the Enterprise Resource Planning system. Enterprise Resource Planning (ERP) Software has brought Enterprise Automation in many Omani Companies and played a significant role in presenting the globally accepted most suitable methods and practices to those companies. An ERP system assures that the rational information is always available and helps the Management to make decisions easily and effectively. This report has analyzed the impact of the ERP system on the role of accountants in manufacturing companies in Oman. The research has examined: 1) the impact of the ERP system on accountant performance. And 2) the difficulties faced by the accountants while 
applying the ERP system. This paper has collected data from interviews. The data analysis shows that ERP system does have an impact on the performance of the accountant. The system helped accountants to complete their work more efficiently and have improved their decision-making ability. According to Alleyne and Marshall (2011), the management accounting practice decisions were timeliness, information, technology, and efficiency. The study has reported that the ERP system gives resilience in accessing information, and the ability to adjust to different situation, it has made the accounting works of accountants in Oman, Al Batinah region, easier and time saving. Similar to the findings of the study of Sangster at al. (2009) that with successful implementations of ERP systems, management accountants have more time for other exceptional activities and their role becomes more enhancing. However, according to the findings, the ERP system is a complex system. Accountants have faced numerous challenges and issues while implementing ERP. One of the biggest problems faced by the accountants in Al Batinah region was to utilize the system as it was new to them. Since, ERP system requires its user to have proper knowledge. Aside from switching to a new system, the ERP implementation requires a lot more, which requires a mindset transformation and changes in usual work manners for the accountants. Moreover, the data quality was affected while implementing ERP. While moving the data from different sources to ERP system accountants in Al Batinah region, had to go through the data cleaning process to clear out invalid or duplicate data, which they claimed to be challenging. Furthermore, the study has also found that, even though ERP system helps in reducing cost and improving accountant's performance and work efficiency, implementing the system is expensive and requires proper training and adequate knowledge. However, this research is subject to several limitations.

\section{Theoretical and Contextual Contributions Theoretical Contributions}

Sangster, Leech \& Grabski (2009) have studied the "Impacts of ERP implementations upon management Accounting and upon management accountants."

They have found that the ERP system has affected the performance of management accountants and accounting, moreover, what impact a successful or unsuccessful implementation holds.

However, in this research study we have developed this model where we have added the difficulties faced by the accountants while implementing the ERP system. Furthermore, this study has examined the difficulties that the accountants faced in using the ERP system and the performance impact. The ERP system is the independent variable, it is not affected by other variables. The difficulties are a mediator variable which may increase or decrease the impact in the performance of accountants. The performance of accountants is a dependent variable which is affected by using the ERP system.

\section{Contextual Contributions}

The findings of this study are important to accountants in manufacturing companies as it highlights the impact of ERP on the performance of accountants and the difficulties faced while implementing ERP. The ERP system is one of the most popularly adopted integrated systems, and the manufacturing companies in Al Batinah region are also using this system. This study puts as much as possible into the research gap on the impact of ERP on accountants at manufacturing companies in developing countries like Oman. There are very few researches done on the impact of ERP on the accountant's performance in manufacturing 
companies in Oman. Moreover, the academics and practitioners can use the findings of this study to effectively comprehend how ERP impacts the accountant's performance and the difficulties they have faced during the ERP implementation and can help to improve the performance of their businesses.

\section{Recommendations for Future Research}

Future research related to the impact of ERP on accountants can provide a more in-depth understanding of ERP systems' impacts on accountants' performance. Future research can prolong the present one to various extents. First of all, the present study is focused only on Omani manufacturing companies in the Al Batinah region, which affected the finding of the study. Therefore, more comprehensive research in the future will provide widespread information involving other companies in different regions of Oman or other countries. Secondly, the literature review explained in the report is limited. Therefore, more studies are needed to be added to the literature about Omani manufacturing companies and the implementation of ERP in Oman and its impact on the performance of the firms which will help in understanding the impact of ERP on accountants in Oman more accurately. Thirdly, future research should strive to examine the level of ERP implementation success. Moreover, in recent years the global financial crisis because of COVID-19 has caused an economic decline which caused huge fluctuations in prices of goods and services and increased market competition. This impact on the global market will have a notable impact on Oman's economy. So, future research should investigate the role economic crisis played in motivating ERP implementation. Finally, based on Rababah (2012) study we encourage the future researchers to use mixed method quantitative and qualitative to collect more deep and accurate data.

\section{References}

Agaoglu, M., Yurtkoru, E. S., Ekmekci, A. K. (2015). The effect of ERP implementation CSFs on business performance: an empirical study on users' perception. Procedia - Social and Behavioral Sciences, 35-42.

Alleyne, P., \& Marshall, D. W. (2011). An Exploratory Study of Management Accounting Practices in Manufacturing companies in Barbados. International journal of Business and Social Science 2(No. 9/ Special Issue May 2011), 49-59.

Fadzil, F. H. B., and Rababah, A. (2012). Management Accounting Change: ABC Adoption and Implementation. Journal of Accounting and Auditing: Research and Practice, 2012, 1-17

Fang, A., Yi-jun, I., Ben-nan, S., \& Qiang, Y. (2009). The Process of ERP Usage in Manu-facturing Firms in China: 2009 International Conference on Management Science \& Engi-neering, 3-9.

Faudziah, K., and Rababah, L. (2011). Adoption and implementation of activity based cost-ing system in Jordanian manufacturing companies. Published at the International Business Information Management Conference (17th IBIMA). Milan, Italy.

Galani, D., Gravas, E., \& Stavropoulos, A. (2010). The Impact of ERP Systems on Account-ing Process. World Academy of Science, Engineering and Technology International Journal of Economics and Management Engineering, 774-779.

Grabski, S., Leech, S., Sangster, A., Grabski, S., Leech, S., \& Sangster, A. (2009). The Impact of ERP Systems on Management Accountants and Their Work. In Management Accounting in Enterprise Resource Planning Systems (pp. 103-115). CHARTERED INST MANAGEMENT ACCOUNTANTS. https://doi.org/10.1016/B978-1-85617-679-8.00008-4 
Hasan, A. (2017). Implementation Problems of Activity Based Costing: A Study of Compa-nies in Jordan. British Journal of Economics, Management and Trade 17 (1), 1-9.

Heele, K. (2019). Benefits of Using an ERP System for Your Accounting. Nascct.

Indra, Adi, L. D., Noorlailie, S., \& Isnalita. (2018). Impact of enterprise resource planning systems on the accounting information relevance and firm performance. Rjoas, 81-81.

Labarre, O., \& Anderson, S. (2021). Enterprise Resource Planning (ERP). Investopedia. https://www.investopedia.com/terms/e/erp.asp

Muscatello, R. J., Small, H. M., \& Chen, J. I. (2003). Implementing enterprise resource planning (ERP) system in small and mid-size manufacturing firm. International Journal of Opera-tions \& production management, 850-871.

Nassar, M., and Rababah, A. (2020). Accounting Problems Influencing the Diffusion of Nanotechnology Implementation in Developing Countries: The Case of Jordanian Companies. International Journal of Innovation, Creativity and Change. Volume 14, Issue 5, 2020.

Rababah, A. (2012). The Implementation Stage of Activity Based Costing Systems inJorda-nian Manufacturing Shareholding Companies (Doctoral dissertation, Universiti Utara Malaysia).

Rbaba'h, A. (2013). The influence of Company Characteristics Factors to Activity Based Costing System Implementation. Journal of Education and Vocational Research, 4 (2): pp. 36-46. - (2014). The Implementation of Management Accounting Innovations "The Case of Balanced Scorecard Implementation within Jordanian Manufacturing Companies", Interna-tional Review of Management and Business Research, 3(1), 174-181.

Sangster, A., Leech A. S., \& Grabski, S. (2009). ERP implementation and their impact upon management accountants. Journal of Information Systems and Technology Management, 125-142.

Seos, G. (2013). Challenges in Implementing Enterprise Resource Planning (ERP) System in large organizations: Similarities and Differences Between Corporate and University Environment. MIT Sloan School of Management, 1-56.

Sunarni, C. W. (2013). Management Accounting Practices and the Role of Management Accounting: Evidence from Manufacturing Companies throughout Yogyakarta, Indonesia. Rev. Integr. Bus. Econ. Res., 616-626.

Swapnil, \& Mullick, S. (2010). Proposal for investigating and prototyping an ERP system for university information functions. BRAC University. http://hdl.handle.net/10361/788

Syida, A. S., Nawawi, A., \& Salin, A. S. (2016). Impact of Enterprise Resource Planning on Management Control System and Accountants' Role. Int. Journal of Economics and Man-agement, 93-1. 